\title{
Bioaccumulation of Pyrethroid in Parasite Wenyonia acuminata (Cestoda: Caryophyllaeidae) and Host fish Synodontis clarias (Linnaeus, 1758) from Lekki Lagoon, Lagos Nigeria
}

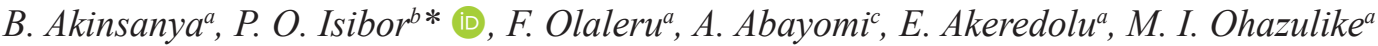 \\ and J. K. Saliu \\ ${ }^{a}$ University of Lagos, Department of Zoology, Akoka, Lagos, Nigeria \\ ${ }^{b}$ Covenant University, Department of Biological Sciences, Ota, Ogun State Nigeria \\ 'University of Lagos, Department of Chemistry, Akoka, Lagos, Nigeria \\ *e-mail: patrickisibor007@gmail.com
}

Received: April 10, 2020 - Accepted: June 18, 2020 - Distributed: August 31, 2021

(With 4 figures)

\begin{abstract}
This study was aimed at determining the concentration of pyrethroid in the surface water, sediment, Weyonia acuminata and Synodontis clarias fish in Lekki lagoon, Lagos, Nigeria. In-situ physicochemical analysis of the surface water was conducted using a calibrated handheld multi-parameter probe (Horiba Checker Model U-10). Intestinal samples from infected and uninfected fish were analyzed for pyrethroid concentrations, microbial colonization, proteins (PRO), superoxide dismutase (SOD), catalase (CAT), reduced glutathione (GSH), malonaldehyde (MDA) and glutathione peroxidase (GPx). The histopathology of infected and uninfected intestinal tissues were analyzed using Haematoxylin and Eosin (H\&E) stains and examined under a binocular light microscope (Model 230485). A total of 39 out of 98 S. clarias fish were infected with cestode parasite, Wenyonia acuminate, amounting to $39 \%$ parasite prevalence. Among the tested pyrethroids, Cyfluthrin and Alpha-cypermethrin had significant sorption of 1.62 and 3.27 respectively from the aqueous phase to the bottom sediment of the lagoon. Pyrethroid concentration was in the order of sediment $>$ parasite $>$ water $>$ intestine $>$ liver. The cholesterol, triglycerides, and LDL (low density lipids) in the parasite were higher than in the host fish $(\mathrm{p}<0.05)$. On the other hand, the fish hepatic protein, high density lipids (HDL) and glucose were higher than the levels in the parasites $(p<0.05)$. There was a high prevalence of gut microbes $(30-40 \%)$, which include Salmonella sp, Escherichia coli, Pseudomonas $s p$ and Bacillus sp among individuals infected with gut Cestodes, Wenyonia sp compared with uninfected individual which had higher gut Staphylococcus sp., Klebsiella sp., and Proteus sp. (10-40\%). among the congeners of pyrethroids analyzed, Cyfluthrin > Alpha-Cyermethrin had significant sorption on the sediment, however unlike a benthopelagic fish, no pyrethroid was accumulated in the S. clarias from the sediment. The fish however accumulated Alpha-Cypermethrin from the aqueous phase. The parasite on the other hand accumulated Bathroid significantly from the surface water and bottom sediment which may be linked to the higher stress levels observed in the parasite than the host fish. The parasite in turn inflicted histological alterations on the host intestine, marked by moderate inflammation of mucosa, alteration of the villi microstructure, moderate stunting of the villous structure and moderate fibrosis of villous structure. The study demonstrated the efficiency of histopathological and microbial analysis in biomonitoring studies enteric parasites and early detection of pyrethroid toxicity respectively compared to bioaccumulation analysis.
\end{abstract}

Keywords: pyrethroid, bioaccumulation, toxicity, enteric parasite, benthopelagic fish, oxidative stress.

\section{Bioacumulação de piretroide no parasita Wenyonia acuminata (Cestoda: Caryophyllaeidae) e peixe hospedeiro Synodontis clarias (Linnaeus, 1758) da lagoa de Lekki, Lagos, Nigéria}

\section{Resumo}

Este estudo teve como objetivo determinar a concentração de piretroide nos peixes de águas superficiais, sedimentos, Wenyonia acuminata e Synodontis clarias na lagoa de Lekki, Lagos, Nigéria. A análise físico-química in situ da água de superfície foi realizada usando uma sonda multiparâmetro manual calibrada (Horiba Checker Modelo U-10). Amostras intestinais de peixes infectados e não infectados foram analisadas quanto a concentrações de piretroides, colonização microbiana, proteínas (PRO), superóxido dismutase (SOD), catalase (CAT), glutationa reduzida (GSH), malonaldeído (MDA) e glutationa peroxidase (GPx). A histopatologia dos tecidos intestinais infectados e não infectados 
foi analisada usando manchas de Hematoxilina e Eosina (H\&E) e examinada sob um microscópio de luz binocular (Modelo 230485). Um total de 39 dos 98 peixes de S. clarias foi infectado com o parasita cestoide Wenyonia acuminata, totalizando $39 \%$ de prevalência do parasita. Entre os piretroides testados, ciflutrina e alfa-cipermetrina tiveram sorção significativa de 1,62 e 3,27, respectivamente, da fase aquosa ao sedimento de fundo da lagoa. A concentração de piretroides estava na ordem de sedimentos $>$ parasita $>$ água $>$ intestino $>$ fígado. $\mathrm{O}$ colesterol, os triglicerídeos e o LDL (lipídios de baixa densidade) no parasita foram maiores que no peixe hospedeiro $(\mathrm{p}<0,05)$. Por outro lado, a proteína hepática dos peixes, os lipídios de alta densidade (HDL) e a glicose foram superiores aos níveis nos parasitas ( $\mathrm{p}<0,05)$. Houve uma alta prevalência de micróbios intestinais (30-40\%), incluindo Salmonella sp., Escherichia coli, Pseudomonas sp. e Bacillus sp. entre indivíduos infectados no intestino com o parasita cestoide Wenyonia sp. em comparação com indivíduos não infectados com Staphylococcus sp., Klebsiella intestinal sp. e Proteus sp. (10-40\%). Entre os congêneres dos piretroides analisados, ciflutrina > alfa-cipermetrina teve sorção significativa no sedimento, porém, diferentemente de um peixe bentopelágico, nenhum piretroide foi acumulado no S. clarias do sedimento. No entanto, os peixes acumularam alfa-cipermetrina a partir da fase aquosa. O parasita, por outro lado, acumulou Bathroid significativamente da água superficial e do sedimento do fundo, o que pode estar relacionado aos níveis mais altos de estresse observados no parasita do que no peixe hospedeiro. O parasita, por sua vez, causou alterações histológicas no intestino hospedeiro, marcadas por inflamação moderada da mucosa, alteração da microestrutura das vilosidades, atrofia moderada da estrutura das vilosidades e fibrose moderada da estrutura das vilosidades. O estudo demonstrou a eficiência da análise histopatológica e microbiana nos estudos de biomonitoramento de parasitas entéricos e detecção precoce da toxicidade dos piretroides, respectivamente, em comparação à análise de bioacumulação.

Palavras-chave: piretroide, bioacumulação, toxicidade, parasita entérico, peixe bentopelágico, estresse oxidativo.

\section{Introduction}

The use of synthetic pesticides has been greatly favored in modern agricultural practices aimed at improved yields. The term pesticide covers a wide range of compounds including insecticides, fungicides, herbicides, rodenticides, molluscicides, nematicides, among others (Ojo, 2016). Pyrethroids are the synthetic analog of pyrethrins which belong to a family of compounds derived directly from either a species of Chrysanthemum flower (pyrethrins) or manufactured model of these chemicals (pyrethroids). They are highly nonpolar chemicals with low solubility and volatility in water with high octanol-water partition coefficient hence, they readily bind to sediment and taken up by lipids (CPCN, 2001; Laskowski, 2002).

The use of pyrethroid insecticides has been on the increase over the past two decades, suddenly emerging as one of the most applied among various classes of insecticides for pest control in a wide variety of crops (Spurlock and Lee, 2008). They are most commonly applied in ultra-low volume aerosol applications used in insecticide spray cans (Chandola et al., 2011).

In recent times, the unregulated application of pesticides has become predominant in Nigeria particularly in Lagos metropolis (Ayejuyo et al., 2008), due to the need to meet the heightened food demand of the exponentially rising population. According to Sofoluwe et al. (2013), an estimated 125, 000-130, 000 metric tonnes of pesticides are applied yearly in Nigeria. Alani et al. (2013) reported high levels of organochlorine pesticides (OCPs) and other persistent, bio-accumulative, and toxic (PBT) organic micro-pollutants in the soil samples of Iddo and Okobaba areas of Lagos, Nigeria. More recently, Akinsanya et al. (2019) reported residues of OCPs the water, soil, and Synodontis clarias sampled from Lekki lagoon which were linked to the unregulated prevalent use of pesticides around the catchment area of the lagoon (Akinsanya et al., 2007; Ayejuyo et al., 2008).

Pyrethroids are known to be highly toxic to non-target organisms, particularly invertebrates and aquatic organisms, which are exposed through surface run-offs and drains from farmlands and residential areas particularly during heavy precipitation (Kronvang et al., 2003). Comprehensive studies have shown that pyrethroids readily adsorb on particulates and precipitate to the bottom of aquatic habitats thereby greatly reducing the concentration in the aqueous phase thus reducing their bioavailability to demersal fish (Yang et al., 2006; Cui et al., 2010). For these reasons, many authors have argued that pyrethroid contamination in freshwater systems is detrimental only to benthopelagic fish and sediment-dwelling organisms (Schleier 3rd and Peterson, 2013).

Pesticides in the aquatic environment can have synergistic, antagonistic, or supra-additive interactions with other environmental stressors such as parasites, temperature, $\mathrm{pH}$, suspended particulates, and other physicochemical parameters (Sures, 2008; Saliu et al., 2014; Akinsanya et al., 2015) in bottom-dwelling fish. Histological and biochemical effects of pyrethroids at low concentrations have been widely reported (Velisek et al., 2006; Ayoola and Ajani 2008; Korkmaz et al., 2009) as reliable physiological endpoints that may signal early warning (Moore and Waring, 2001; Werner and Moran, 2008; Angahar, 2017). As delayed intervention may result in fish kills, reduced fish productivity, and general public health concerns. Although Synodontis clarias has great commercial value, particularly in the nearby fish markets where it is conserved an exotic animal protein, being a benthic organism and mud dweller, the fish is however highly susceptible to pyrethroid exposure in Lekki lagoon (Singh et al., 2002; Yim et al., 2005; Wei et al., 2014), as they readily store up the sediments-bound hydrophobic 
contaminants (Qadir and Malik, 2011; Ccanccapa et al., 2016).

The study was aimed at determining the concentrations of pyrethroids in the liver, intestine, and enteric parasites of $S$. clarias with the associated sub-lethal effects using histopathology and biochemical marker analysis. The findings may help in making informed policies for the protection of the lagoon and the dependent populace.

\section{Material and Methods}

\subsection{The study area}

The study area was Lekki lagoon (longitudes 4 001' and 4015' E; latitudes 6025' and 6037' N) Lagos State, Nigeria (Figure 1). The lagoon supports a major fishery in Nigeria, with a surface area of about $247 \mathrm{~km}^{2}$, a maximum depth of $6.4 \mathrm{~m}$.

The Oni River and the Osun and Saga River drains into the lagoon from the Northeast, while the Osun and Saga River flows in from the Northwest. As a major feature of the southern part of Nigeria, Lekki lagoon experiences the rainy and dry seasons. Shrubs and Raphia palms are the major make-up of the surrounding vegetation of the lagoon. The most dominant is Raphia sudanica and then oil palms, Elaeis guineensis. The lagoon borders are marked by floating grasses while the surrounding communities are dominated by coconut palm; Cocus nucifera vegetation.

\subsection{Collection and analysis of water and sediment samples}

Water and sediment samples were collected from four (4) stations in Lekki Lagoon. The four locations were characterized by different farming activities, the presence of abattoir, and anchoring of fishermen's boat. These activities discharge their effluents into the water body which may influence the water quality and consequently endanger aquatic organisms inhabiting the water.
Water samples were scooped using clean and unused 1litre sampling bottles. The samples were kept in flasks with ice packs and transported to the laboratory of the Zoology Department, University of Lagos, where they were further refrigerated at $4{ }^{\circ} \mathrm{C}$ before analysis. Physiochemical parameters measured in situ include temperature, using a mercury-in-glass thermometer, while salinity, dissolved oxygen, $\mathrm{pH}$ (hydrogen ion concentration), Turbidity, total suspended solids (TSS) and total dissolved solids (TDS), and conductivity were measured using a handheld multi-parameter probe (Horiba Water CheckerModelU-10).

Soil samples were collected using Van Veen grab sampler (dimension: $5 \mathrm{~g} ; 15 \times 15 \mathrm{~cm}$ ) at each station and were stored immediately in polythene bags, and transported to the laboratory in an iced cooler for analysis.

\subsection{Fish sample collection}

A total of 98 randomly selected fresh samples of Synodontis clarias were purchased from local fishmongers at the lagoon within the periods of July- November 2019. Morphometrics (weight and standard length), sex determination, and organs excision (liver and intestine) were done at the site of sample collection. The fish samples were identified using Kusemiju (1981), FAO (1996), Olaosebikan and Raji (1998); and Idodo-Umeh (2003).

\subsubsection{Morphometric parameters}

Fish weights were measured with a digital electronic weighing balance (Ohaus CS5000) and recorded to the nearest gram (g). The standard length (SL) of each individual was measured from the tip of the snout to the posterior caudal peduncle using a measuring tape and recorded to the nearest centimeter $(\mathrm{cm})$. The sexes of the specimen were determined based on the presence of testicles in males and ovaries in females.

The length-weight relationship was determined using correlation and regression analyses. Scattered diagrams were plotted to determine the regression intercept and slope.

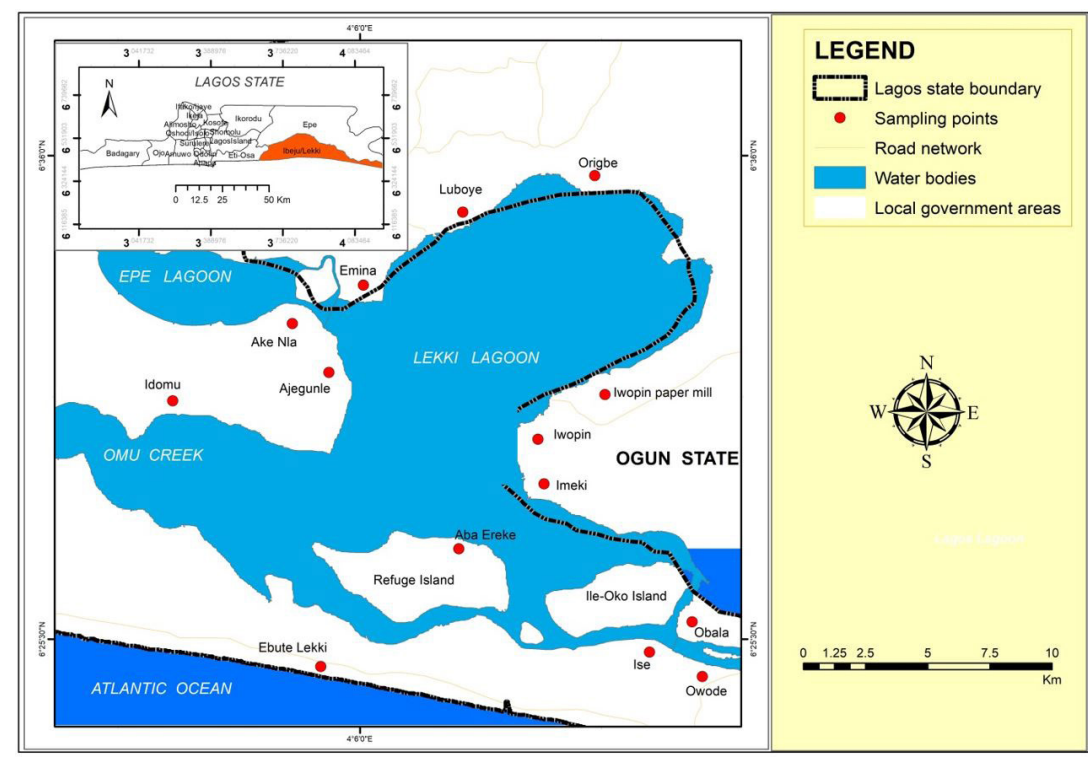

Figure 1. Map of Lekki Lagoon. 
The length weight relationship of the fish individuals was analyzed using the cubed law stated by LeCren (1951):

$W=a L^{b}$

$\mathrm{W}=$ fish Weight $(\mathrm{g}), \mathrm{L}=$ standard length $(\mathrm{TL})$ of the fish $(\mathrm{cm})$, 'a' and 'b'= regression intercept and slope respectively.

The logarithmic expression of Equation 1 above is $\log W=\log a+b \log L$.

The condition factor of the fish was determined as a measure of energetics, nutritional status, and viability of the host. Fish species are hosts to taxonomically diverse parasites, and infections can significantly affect fish behavior, metabolism, body condition, fecundity, and survival.

The length and weight measurements recorded for each fish sample were used in calculating the condition factor of the fish (Equation 2). The formula employed was;

$K=\frac{100 W}{L^{\text {bor } 3}}$

$\mathrm{K}$ is Fulton's condition factor, $\mathrm{W}$ is the weight of the fish measured in $(\mathrm{g}), \mathrm{L}$ is the standard length of the fish measured in $(\mathrm{cm}), \mathrm{b}$ is the value obtained from the growth exponent in the length.

\subsubsection{Excision of visceral organs and examination of parasites}

Each labeled fish sample was ventrally excised from the posterior, through the stomach. During this process, the utmost precaution was taken to prevent mechanical damage to the tissues and organs. The liver and intestine were carefully eviscerated and preserved in normal saline.

The techniques of Akinsanya et al. (2015) were adopted for the examination of gastrointestinal parasites in the fish samples. The intestines were excised longitudinally to aid the emergence of the parasites. The intestines collected for histology were stored in Bouin's fluid before analysis.

The intestines from both infected and uninfected fish were prepared for histological analysis after dissection. The intestines were placed in bottles containing bouins fluid for $6 \mathrm{~h}$, after when it was decanted and $10 \%$ buffered formalin was added to preserve the tissue. Random selection was made from the preserved tissues based on infection status. The tissues were routinely dehydrated in an ascending series of alcohol at $30 \mathrm{~min}$ interval. It was then embedded in molten paraffin wax and allowed to solidify. The blocked tissues were sectioned at 4-5 microns processed and stained with Haematoxylin and Eosin (H\&E) stains. The stain was rinsed off in with distilled water while the over stained with $1 \%$ alcohol. The tissues were mounted using DPX mountant, dried, and examined under a binocular light microscope (Model 230485). The photomicrograph was taken to the pathology laboratory of the Department of Veterinary Pathology, University of Ibadan, Nigeria.

\subsubsection{Determination of pyrethroids in environmental media}

The distribution of pyrethroid insecticides in Lekki Lagoon and the fish Synodontis clarias was assessed by measuring the concentrations in surface water, sediment samples, fish liver, intestine, and intestinal parasite.

\subsubsection{Determination of pyrethroids in sediment}

EPA Method 3500C, 3550B was used to determine the concentrations of pyrethroids in the sediment samples. The homogenized sediment sample was sieved through $10 \mu \mathrm{m}$ mesh size to remove debris and $10 \pm 0.05 \mathrm{~g}$ was weighed into $250 \mathrm{~mL}$ Teflon bottle. About 1-3 spatula full of activated sodium sulfate was added to the samples in the Teflon bottles to eliminate water/aqueous portions. Extraction was done thrice using $20 \mathrm{~mL}$ of 1:1 acetone: hexane, giving $\sim 60 \mathrm{~mL}$ of final extracting solvent. The covered Teflon bottles were then sonicated in an ultrasonic bath at $70^{\circ} \mathrm{C}$ for $30 \mathrm{~min}$. The organic layer was decanted into a clean beaker/round-bottom flask, further dried with sodium sulfate and clean-up procedure using a silica gel column. The sample extract was then concentrated to $\sim 2 \mathrm{~mL}$ using a rotary evaporator before pyrethroids analysis using a gas chromatography-mass spectrometer (GC-MS).

\subsubsection{Determination of pyrethroids in water}

Using method: EPA Method $3510 \mathrm{C}, 100 \mathrm{ml}$ of the water sample was extracted thrice with $20 \mathrm{~mL} 1+1$ Hexane: Acetone In a $250 \mathrm{~mL}$ separatory funnel, giving $\sim 60 \mathrm{~mL}$ of final extracting solvent. The content was vigorously agitating/shaking the separatory funnel for 5 mins while periodically venting to the funnel to release excess pressure build-up. The sample organic extract layer was carefully decanted, dried with sodium sulfate, and clean-up procedure using a silica gel column carried out. The sample extract was then concentrated using a rotary evaporator to $\sim 2 \mathrm{~mL}$ for pyrethroids analysis using a gas chromatography-mass spectrometer (GC-MS).

\subsubsection{Determination of pyrethroids in fish tissues}

$\mathrm{KOH}$ refluxing/vortex extraction was employed in testing for pyrethroid in the intestines, livers, and parasites of the fish samples, while EPA Method 3611C was used in the clean-up process.

Liver, intestinal tissue samples (15g wet weight) and pooled parasite samples $(0.5 \mathrm{~g})$ were weighed separately into a crucible then macerate and homogenized., then $10 \mathrm{~g}$ of the homogenized tissue was placed in a $50 \mathrm{~mL}$ centrifuge tube, $15 \mathrm{~mL}$ of $6 \mathrm{~N} \mathrm{KOH}$ was added, the tubes were sealed and incubated for $18 \mathrm{~h}$ in a $35^{\circ} \mathrm{C}$ water bath, shaking vigorously for $30 \mathrm{sec}$ for every $1 / 2$ hour for the first 4 hours. The sample was allowed to cool. $15 \mathrm{~mL}$ of methylene chloride was added to a centrifuge tube, vortex for $1 \mathrm{~min}$, and centrifuge at $2000 \mathrm{rpm}$ for $5 \mathrm{~min}$ to facilitate phase separation. The upper/aliquot layer was removed using a Pasteur pipette into a $250 \mathrm{~mL}$ round-bottom flask. Solvent centrifugation was repeated twice and all aliquots fractions combined in the round-bottom flask. Sample extracts concentration to about $5-10 \mathrm{~mL}$ is carried out by rotary evaporator before fractionation clean up using alumina gel column and GC-MS analysis.

The determination of the levels of pyrethroids in the samples was carried out using GC-MS. Pyrethroids standard (100ppm) was purchased from Accu Standard. Five (5) point serial dilution calibration standards $(1.00,5.00,10.00,50.00,100.00 \mathrm{ppm})$ were prepared from the stock and used to calibrate the GC-MS. 
Agilent 7890B gas chromatography coupled to a mass spectrometer (MS) was used. The stationary phase of separation of the compounds was HP-5 capillary column coated with 5\% Phenyl Methyl Siloxane (30m length $\mathrm{x} 0.32 \mathrm{~mm}$ diameter $\mathrm{x} 0.25 \mu \mathrm{m}$ film thickness) (Agilent Technologies). $1 \mu \mathrm{L}$ of the samples were injected in pulsed splitless mode at an injection temperature of $250^{\circ} \mathrm{C}$, at a pressure of $0.23311 \mathrm{psi}$, and a total flow of $31.258 \mathrm{~mL} / \mathrm{min}$. Purge flow to split vent was set at $30 \mathrm{~mL} / \mathrm{min}$ at $0.35 \mathrm{~min}$. The oven was initially programmed at $80^{\circ} \mathrm{C}(1 \mathrm{~min})$ then ramped at $10^{\circ} \mathrm{C} / \mathrm{min}$ to $300^{\circ} \mathrm{C}(10 \mathrm{~min})$. The total run time was 33 mins. The mass spectrometer was operated in the electron impact mode with an ion source temperature of $250^{\circ} \mathrm{C}$ and the electron impact energy was set at $70 \mathrm{eV}$. The MS scanned mass range $\mathrm{m} / \mathrm{z} 40$ and 300 were used for quantitative determinations of the studied pesticides. For quantitative determination using selective ion monitoring (SIM), pesticides were identified by ions with the following $\mathrm{m} / \mathrm{z}$ values and quantified by the ions 87,93 , and 125 . Quantification was performed by calculating the absolute peak areas. After calibration, the samples were analyzed and corresponding pyrethroids concentration obtained.

\subsubsection{Biochemical analysis}

The liver, intestine, and intestinal parasites were removed from 10 randomly selected fish. The samples were washed in an ice-cold of $1.15 \% \mathrm{KCL}$ solution, blotted, and weighed. They were then homogenized with a $0.1 \mathrm{M}$ phosphate buffer (PH 7.2). The organs were put into mortar and laboratory sand (acid-washed sand) added to it before blending with a pestle. The resulting homogenate was centrifuged at $2500 \mathrm{rpm}$ for $15 \mathrm{mins}$ before removal and supernatant were decanted and stored until $20^{\circ} \mathrm{C}$ before further analysis.

\subsubsection{Determination of total protein}

Protein molecules are composed of amino acids arranged in long chains called peptide chains. The links which join the amino acids together are known as peptide bonds. In the Biuret reaction, the cupric ions in the reagent join with the peptide bonds of the protein molecules in an alkaline solution to form a blue-violet colored complex.

Using the Biuret method, $3.0 \mathrm{~g}$ of copper sulfate (CUS045H2O) crystals were dissolved in about $500 \mathrm{ml}$ of Distilled water and add $9.0 \mathrm{~g}$ of potassium tartrate and $5.0 \mathrm{~g}$ of potassium Iodide (KI). $100 \mathrm{ml}$ of $6 \mathrm{M}$ sodium hydroxide $(\mathrm{NaOH})$ solution was added and the mixture made up to 1litre with distilled water. When kept in a tightly-stoppered polyethylene bottle, this solution is stable indefinitely at $20-25^{\circ} \mathrm{C}$. The absorbance of the color produced was measured in a spectrophotometer at $540 \mathrm{~nm}$.

$9.0 \mathrm{~g}$ of potassium sodium tartrate and $5.0 \mathrm{~g}$ was dissolved in clean water. $100 \mathrm{ml}$ of $6 \mathrm{M} \mathrm{NaOH}$ solution was added and the mixture diluted with water to make up to 1 litre. When kept in a tightly stoppered reagent 50 bottle. This solution is stable indefinitely at $20-25^{\circ} \mathrm{C}$.

\subsubsection{Determination of superoxide dismutase (SOD)}

Superoxide Dismutase activity in liver homogenates was determined using Marklund and Marklund's (1974) procedure with some modifications. The method is based on the ability of SOD to inhibit the autoxidation of pyrogallol. In $970 \mu \mathrm{L}$ of buffer (100 mMTris - HCl, 1mM EDTA, pH 8.2), $10 \mu \mathrm{L}$ of homogenates and $20 \mu \mathrm{L}$ pyrogallol $13 \mathrm{mM}$ were mixed. The assay was performed in thermostated cuvettes at $25^{\circ} \mathrm{C}$ and changes in absorption were recorded by a spectrophotometer (Spectronic 20D) at 480nm. One unit of SOD activity was defined as the amount of enzyme that can inhibit the auto-oxidation of $50 \%$ of the total pyrogallol in the reaction.

\subsubsection{Determination of reduced glutathione (GSH)}

Reduced glutathione (GSH) was determined by the method of Ellman (1959). To the liver homogenate 10\% TCA was added and centrifuged. $1.0 \mathrm{ml}$ of supernatant was treated with $0.5 \mathrm{ml}$ of Ellman's reagent (19.8 $\mathrm{mg}$ of 5,5'-dithiobis nitro benzoic acid (DTNB) in $100 \mathrm{ml}$ of $0.1 \%$ sodium nitrates) and $3.0 \mathrm{ml}$ of phosphate buffer $(0.2 \mathrm{M}, \mathrm{pH} 8.0)$. The absorbance was read at $412 \mathrm{~nm}$.

\subsubsection{Determination of catalase (CAT)}

Catalase (CAT) was assayed calorimetrically at $620 \mathrm{~nm}$ and expressed as moles of hydrogen peroxide (H2O2) consumed $/ \mathrm{min} / \mathrm{mg}$ protein as described by Quinlan et al. (1994). The reaction mixture $(1.5 \mathrm{ml})$ contained $1.0 \mathrm{ml}$ of $0.01 \mathrm{M} \mathrm{pH} 7.0$ phosphate buffer, $0.1 \mathrm{ml}$ of Plasma and $0.4 \mathrm{ml}$ of $2 \mathrm{M} \mathrm{H}_{2} \mathrm{O}_{2}$. The reaction was stopped by the addition of $2.0 \mathrm{ml}$ of dichromate-acetic acid reagent (5\% potassium dichromate and glacial acetic acid were mixed in 1:3 ratio). The specific activity of catalase was expressed as moles of reduced per minute per mg protein.

\subsubsection{Determination of Malondialdehyde (MDA)}

Malondialdehyde (MDA) an index of lipid peroxidation was determined by adding $1.0 \mathrm{ml}$ of the supernatant was added to $2 \mathrm{ml}$ of $(1: 1: 1)$ TCA-TBA HCL reagent (thiobarbituric acid $0.37 \%, 0.24 \mathrm{n}$ HCL and $15 \%$ TCA) tricarboxylic acid-thiobarbituric acid-hydrochloric acid reagent boiled at $100^{\circ} \mathrm{C}$ for $15 \mathrm{mins}$ and allowed to cool. Flocculent materials were removed by centrifuging at $3000 \mathrm{rpm}$ for $10 \mathrm{mins}$. The supernatant was removed and the absorbance read at 532 against a blank. MDA was calculated using the molar extinction coefficient for the MDATBA-complex of $1.5 \times 105 \mathrm{M} / \mathrm{cm}$.

\subsubsection{Determination of glutathione peroxidase (GPx)}

Glutathione peroxidase catalyzes the reduction of hydrogen peroxide and lipid peroxide into water and lipid alcohol through the oxidation of reduced glutathione (GSH) into glutathione disulfide (GSSG) (Arthur, 2000). Samples were incubated using hydrogen peroxide in the presence of glutathione for a particular period. The amount of utilized hydrogen peroxide is then determined by directly 5, 5'- estimating GSH content using Ellman's reagent, dithiol bisnitrobenzoic acid (DTNB).

\subsubsection{Determination of lipid profile}

Lipid profiles are commonly used in the routine evaluation of cardiovascular risk, given the high correlations of hypercholesterolemia and hypertriglyceridemia and cardiovascular risk. A standard lipid profile includes determination of serum or plasma total cholesterol (TC), 
high-density lipoprotein-associated cholesterol (HDLC), low-density lipoprotein-associated cholesterol (LDLC), total triglycerides (TG), Total Protein (TP) and Glucose (Gluc-PAP).

\subsubsection{Determination of total cholesterol}

Reagents used include pipes $35 \mathrm{mmol} / 1$, sodium cholate $0.5 \mathrm{mmol} / 1$, phenol $28 \mathrm{mmol} / 1$, cholesterol esterase $>0.2 \mathrm{u} / \mathrm{ml}$, cholesterol oxidase $>0.1 \mathrm{u} / \mathrm{ml}$, peroxide $>0.8 \mathrm{u} / \mathrm{ml}$, 4-aminoantipyrine $0.5 \mathrm{mmol} / 1$.

Cholesterol standard used was cholesterol $200 \mathrm{mg} / \mathrm{dl}$ $(5,18 \mathrm{mmol} / 1)$.

All the reagents were brought to room temperature.

$1.0 \mathrm{ml}$ blank, standard, and sample were pipette into tube labeled Reagent (A); $10 \mu \mathrm{L}$ sample into tube labeled Sample; $10 \mu \mathrm{L}$ standard into tube labeled Cholesterol Standard. All were mixed thoroughly and incubated for $10 \mathrm{mins}$ at room temperature $\left(16-25^{\circ} \mathrm{C}\right)$ or $5 \mathrm{~min}$ at $37^{\circ} \mathrm{C}$. The absorbance $(\mathrm{A})$ is measured for the standard and sample at 500nm against the blank.

The cholesterol concentration in the sample was calculated as shown in Equation 3:

$$
\frac{A \text { sample }}{A \text { standard }} \times C \text { standard }=C \text { sample }
$$

\subsection{Quality assurance and quality control}

Before use, the dissecting instruments and sampling containers used were pre-cleaned using $80 \%$ ethanol and sterilized $121^{\circ} \mathrm{C}$ for $15 \mathrm{~min}$, using a pressure steam sterilizer (Model: SM280E) by Surgifriend Medicals, England. One surgical blade was used per tissue sample, after when it was discarded safely. To avoid hand contamination of samples, sterile laboratory gloves, and nose masks were used throughout the experimental session. All readings were taken in triplicate to minimize errors.
The limits of detection (LOD) and the limits of quantification (LOQ) were calculated based on the standard deviation of 20 readings obtained for the analytical blanks and the slopes of the analytical curves (LOD $=3 \sigma /$ slope and $L O Q=10 \sigma /$ slope) .

\subsection{Statistical analysis}

The condition factors of fish, concentrations of biochemical, and pyrethroid in the various media were subjected to analysis of variance (ANOVA) using the 2007 Excel and SPSS 20 tool packages. The significant differences were further ascertained by Tukey post hoc test all at a probability level of 0.05 .

\section{Results}

\subsection{Physicochemical characteristics of the lagoon}

The temperature range of the lagoon during the study period was $27.2-33.1{ }^{\circ} \mathrm{C}$, with the highest recorded in November $\left(33.1^{\circ} \mathrm{C}\right)$. The entire temperature was within the FME safe limit for surface water temperature (Table 1). The $\mathrm{pH}$ ranged from 3.87- 4.87 was lower than the FME regulatory limit, indicating that the lagoon was slightly acidic between July and November 2019.

In November, the temperature $\left(33.1^{\circ} \mathrm{C}\right)$ and total dissolved solids $(35 \mathrm{mg} / \mathrm{l})$ of the lagoon exceeded the FME regulatory limits, which are $30^{\circ} \mathrm{C}$ and $30 \mathrm{mg} / \mathrm{l}$ respectively.

\subsection{Morphometrics and condition factor of S. Clarias}

A total of 98 fish were weighed $(80.55 \pm 3.56 \mathrm{~g})$ to the nearest $0.01 \mathrm{~g}$ using a digital Camry weighing balance (model EK-1A SERIES) and standard length $(15.62 \pm 2.3 \mathrm{~cm})$ was measured using a thread and ruler. The total condition factor of the fish ranged from 0.96-3.84 (Table 2). The condition

Table 1. Physicochemical characteristics of the surface water of Lekki lagoon.

\begin{tabular}{lcccccccc}
\hline Months & Temperature & $\mathbf{p H}$ & $\begin{array}{c}\text { Electrical } \\
\text { Conductivity } \\
\text { (S/CM) }\end{array}$ & $\begin{array}{c}\text { Turbidity } \\
\text { (NTU) }\end{array}$ & $\begin{array}{c}\text { Dissolved } \\
\text { Oxygen } \\
(\mathbf{m g} / \mathbf{L})\end{array}$ & $\begin{array}{c}\text { Dissolved } \\
\text { Oxygen (\%) }\end{array}$ & $\begin{array}{c}\text { Total } \\
\text { Dissolved } \\
\text { Solids (mg/l) }\end{array}$ & $\begin{array}{c}\text { Salinity } \\
\text { (ppt) }\end{array}$ \\
\hline July & 27.6 & 4.87 & 0.405 & 69.0 & 18.42 & 236.50 & 264 & 0.2 \\
August & 26.2 & 3.87 & 0.162 & 26.4 & 43.14 & 500.00 & 106 & 0.1 \\
September & 26.57 & 3.90 & 0.118 & 45.4 & 4.99 & 63.00 & 77 & 0.1 \\
October & 27.2 & 4.04 & 0.18 & 63.9 & 14.71 & 187.40 & 28 & 0.0 \\
November & 33.1 & 3.49 & 0.242 & 22.5 & 18.72 & 256.60 & 35 & 0.0 \\
Mean & 28.134 & 4.034 & 0.2214 & 45.44 & 19.996 & 248.7 & 102 & 0.08 \\
FME limits & 30.00 & $6.5-8$ & NA & 10.00 & NA & $<2000$ & 30 & NA \\
\hline
\end{tabular}

NA- not available.

Table 2. Morphometrics and condition factor (K) of S.clarias in the lagoon.

\begin{tabular}{llcrrr}
\hline \multicolumn{1}{c}{ Parameters } & N & Minimum & Maximum & Mean & \multicolumn{1}{c}{ SD } \\
\hline Standard Length (cm) & 98 & 10.50 & 19.50 & 15.62 & 1.60 \\
Body Weight (g) & 98 & 31.00 & 168.00 & 80.55 & 24.36 \\
Condition Factor & 98 & 0.96 & 3.84 & 2.09 & 0.48 \\
Female Standard Length (cm) & 45 & 13.50 & 19.50 & 16.29 & 1.40 \\
Female Body Weight (g) & 45 & 54.00 & 147.00 & 88.13 & 24.08 \\
Female Condition Factor & 45 & .96 & 3.33 & 2.05 & 0.47 \\
Male Standard Length (cm) & 53 & 10.50 & 17.80 & 15.04 & 1.55 \\
Male Body Weight(g) & 53 & 31.00 & 168.00 & 74.11 & 22.90 \\
Male Condition Factor & 53 & 1.43 & 3.84 & 2.13 & 0.48 \\
\hline
\end{tabular}

$\mathrm{SD}=$ standard deviation. 
factors of the male and female fish were not significantly different $(\mathrm{p}>0.05)$.

Among the tested pyrethroids, Cyfluthrin, and Alpha-cypermethrin had significant sorption of 1.62 and 3.27 respectively from the aqueous phase to the bottom sediment in the lagoon (Table 3). The cumulative sorption (1.77) of the total pyrethroid was also significant.

Alpha-cypermethrin was the only pyrethroid that was significantly accumulated in the fish intestine from water. No significant accumulation occurred in the intestine from the sediment. Deltamethrin, permethrin, and tetramethrin were not detected in all the environmental media. However, no contaminant was significantly accumulated in the liver of the fish. Baythroid (Beta-Cypermethrin) was the only pyrethroid that was significantly bioaccumulated in the parasite from the surface water and the bottom sediment. The parasite showed a great affinity for Cyfluthrin and Baythroid (Beta-Cypermethrin), characterized by high bioaccumulation of the congeners from the intestine. The total accumulated pyrethroid from the aqueous phase was significant while those accumulated from the sediment were not significant. Pyrethroid concentration was in the order of sediment $>$ parasite $>$ water $>$ intestine $>$ liver.

\subsection{Determination of biochemical markers in S. clarias and W. acuminata}

The cholesterol, triglycerides, and LDL (low-density lipids) in the parasite were higher than in the host fish $(p<0.05)$. On the other hand, the fish hepatic protein, high-density lipids (HDL) and glucose were higher than the levels in the parasites $(\mathrm{p}<0.05)$. The host protein ranged from 23.67-39.14 g/l, mean $\pm \mathrm{SD}=34.46 \pm 4.58 \mathrm{~g} / \mathrm{l}$ (Figure 2).

The activity levels of SOD, CAT, and MDA, in the Wenyonia sp. were significantly higher in the parasite than in the fish liver (Figure 3). More so, SOD ranged was 126.48- $203.88 \mathrm{~min} / \mathrm{mg}$ protein with a mean value of $153.95 \pm 26.11 \mathrm{~min} / \mathrm{mg}$ protein in the fish liver. The MDA levels in the fish liver were $13.46-29.75 \mathrm{nmol} / \mathrm{ml}$ with mean $23.81 \pm 4.86 \mathrm{nmol} / \mathrm{ml}$ while CAT activities ranged $1.23-2.52 \mathrm{~min} / \mathrm{mg}$ protein with mean $1.72 \pm 0.38 \mathrm{~min} / \mathrm{mg}$. The levels of GSH range was $9.07-10.42 \mu \mathrm{mol} / \mathrm{ml}$ with a mean value of $\mu \mathrm{mol} / \mathrm{ml}$ and GPx range was $23.93-36.90 \mu \mathrm{mol} / \mathrm{ml}$ with a mean value of $27.18 \pm 4.28 \mu \mathrm{mol} / \mathrm{ml}$. Meanwhile, in the Wenyonia $s p$. significantly higher peaks of SOD (353.22 $\mathrm{min} / \mathrm{mg}$ protein), $\operatorname{MDA}(24.37 \mathrm{nmol} / \mathrm{ml})$, and CAT activities $(7.05 \mathrm{~min} / \mathrm{mg}$ protein) were recorded $(p<0.05)$. The values of GSH $(7.02 \mu \mathrm{mol} / \mathrm{ml})$

Table 3. Levels of pyrethroid in water and sediment and bioaccumulation in host, S. clarias and parasite, W. acuminata.

\begin{tabular}{|c|c|c|c|c|c|c|c|c|c|c|c|}
\hline Pyrethroids & 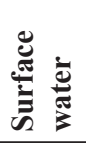 & 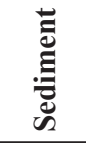 & $\sum_{\infty}^{2}$ & 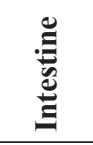 & $\frac{3}{5}$ & 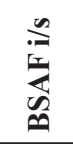 & 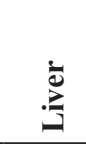 & $\frac{3}{3}$ & 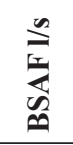 & 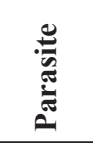 & 突 \\
\hline Cyfluthrin & 7.62 & 12.38 & 1.62 & 6.01 & 0.79 & 0.49 & 6.44 & 0.85 & 0.52 & 6 & 1 \\
\hline Baythroid (Beta-Cypermetrin) & 14.89 & 14.7 & 0.99 & 13.67 & 0.92 & 0.93 & 14.11 & 0.95 & 0.96 & 17.94 & 1.3 \\
\hline Alpha-Cypermethrin & 8.61 & 28.13 & 3.27 & 8.6 & 1 & 0.31 & 7.59 & 0.88 & 0.27 & 7.78 & 0.9 \\
\hline Delta-methrin & 0 & 0 & & 0 & & & 0 & & & 0 & \\
\hline Permethrin & 0 & 0 & & 0 & & & 0 & & & 0 & \\
\hline Tetramethrin & 0 & 0 & & 0 & & & 0 & & & 0 & \\
\hline Sum of Pyrethroids & 31.12 & 55.21 & 1.77 & 28.28 & 0.91 & 0.51 & 28.14 & 0.9 & 0.51 & 31.72 & 3.2 \\
\hline
\end{tabular}

Emboldened figures are significant. $\mathrm{K}_{\mathrm{sw}}=$ sorption of pyrethroid from aqueous phase to sediment. $\mathrm{BAF} \mathrm{i}_{\mathrm{w} / \mathrm{w}}=$ bioaccumulation factor

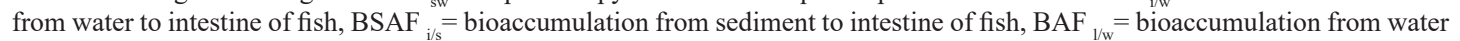
to liver of fish, $\mathrm{BSAF}_{1 / \mathrm{s}}=$ bioaccumulation from soil to liver of fish, $\mathrm{BAF}_{\mathrm{p} / \mathrm{i}}=$ bioaccumulation from intestine to parasite.

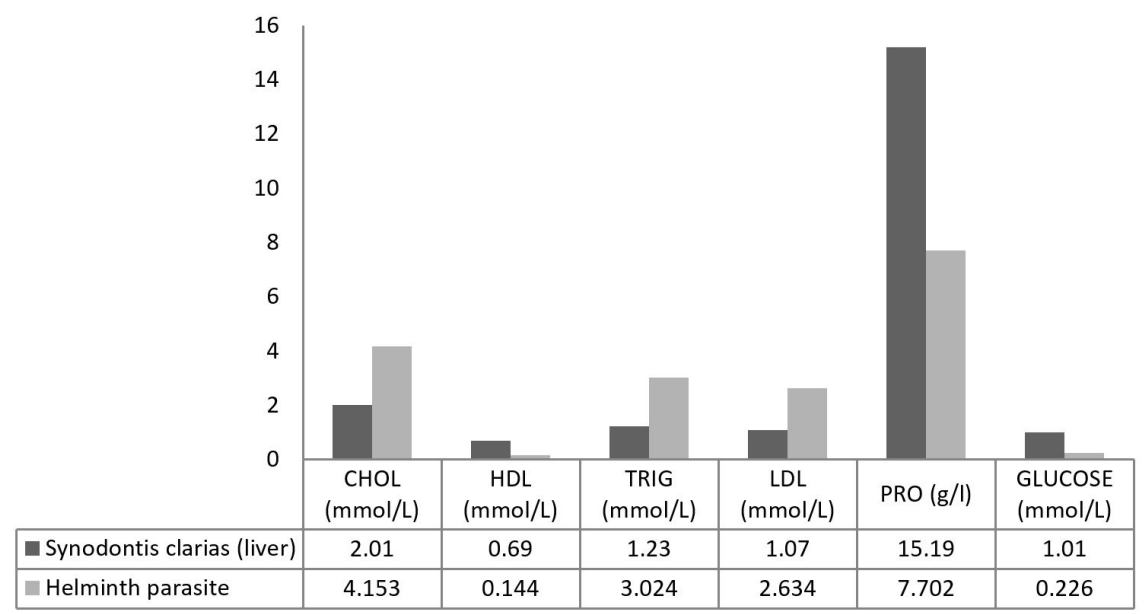

Figure 2. Biochemical profile in the intestines of S. clarias and its parasite Wenyonia sp CHOL- cholesterol, HDL- high density lipids, TRIG- triglycerides, LDL- low density lipids, PRO- hepatic protein. 
and $\mathrm{GP}_{\mathrm{X}}(50.46 \mu \mathrm{mol} / \mathrm{ml})$ in the parasite did not however vary significantly from the liver of the hot fish.

\subsection{Microbial load in the intestine and on the skin of S. Clarias}

The prevalence of microbes in the gut of the infected and uninfected individuals of $S$. clarias in the lagoon (Table 4) showed a higher prevalence in the infected fish compared to the uninfected counterparts, particularly in the cases of Proteus sp. and Escherichia coli which were $40 \%$ and $10 \%$ for infected and uninfected fish respectively.

In terms of the overall prevalence of microbes on the epidermis of the fish irrespective of the infection status (Table 5), the bacteria, Bacilus sp. recorded the highest prevalence (80\%), while Mucor sp. was the least prevalent $(6.7 \%)$.
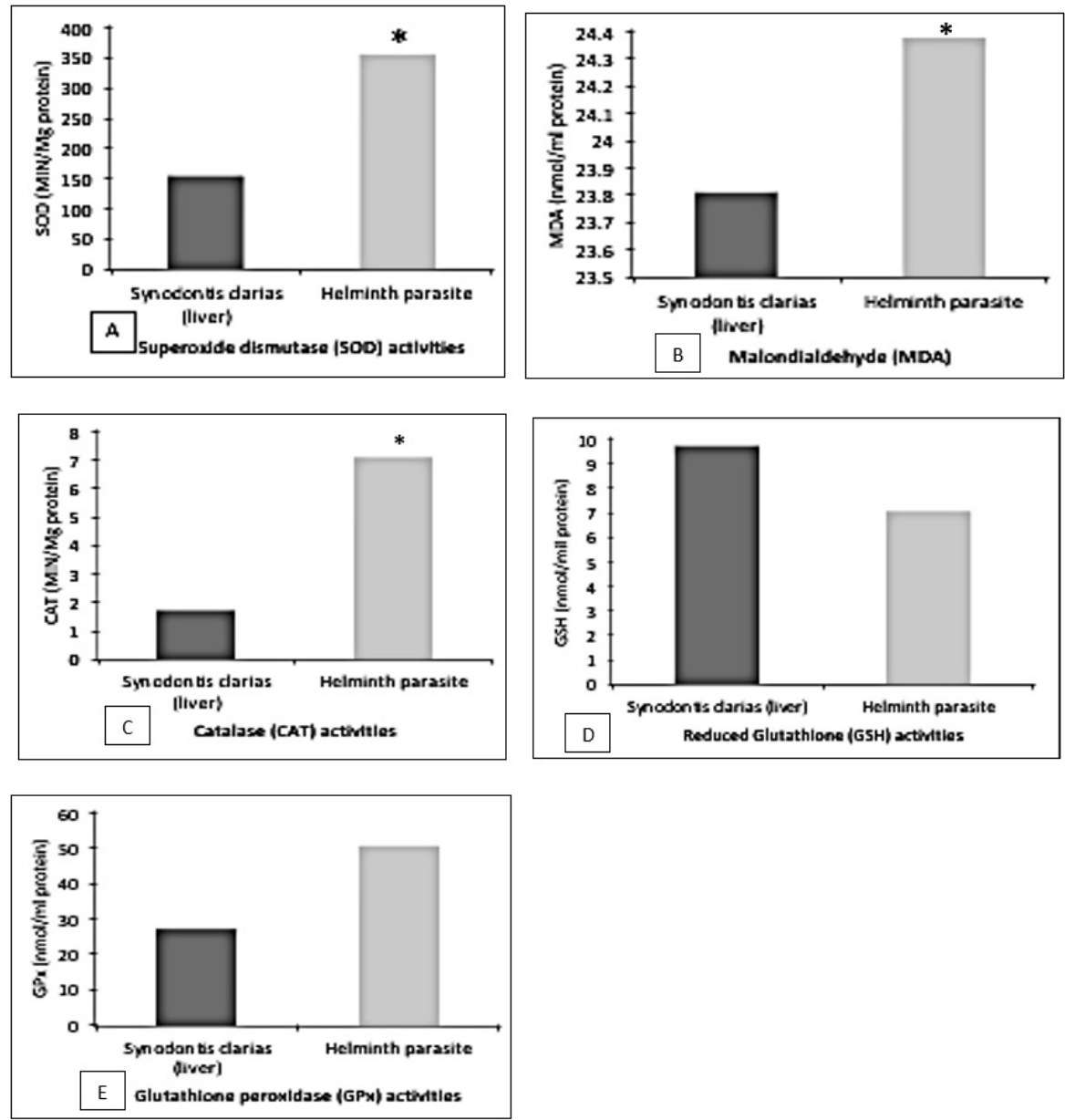

Figure 3. Comparative analysis of activities of biochemical markers in S. clarias and the enteric parasites. Asterisked bars are significantly higher than non-asterisked ones $(p<0.05)$.

Table 4. Prevalence of microflora in the infected and uninfected intestines of $S$. clarias in Lekki Lagoon.

\begin{tabular}{lcc}
\hline $\begin{array}{c}\text { Identified Microbial } \\
\text { Cultures }\end{array}$ & $\begin{array}{c}\text { Infected fish } \\
(\mathbf{\%})\end{array}$ & $\begin{array}{c}\text { Uninfected } \\
\text { fish } \mathbf{( \% )}\end{array}$ \\
\hline Salmonella sp. & 46.7 & 36.0 \\
Staphylococcus sp. & 36.7 & 40.0 \\
Klebsiella sp. & 46.7 & 30.0 \\
Proteus sp. & 40.0 & 10.0 \\
Escherichia coli & 40.0 & 10.0 \\
Pseudomonas sp. & 20.0 & 15.0 \\
Bacillus sp. & 33.3 & 22.5 \\
\hline
\end{tabular}

Table 5. Microbial load on the skin of fish sample from Lekki Lagos.

\begin{tabular}{lcc}
\hline \multicolumn{1}{c}{ Species } & $\begin{array}{c}\text { Number of } \\
\text { occurrence }\end{array}$ & $\begin{array}{c}\text { Prevalence } \\
(\mathbf{\%})\end{array}$ \\
\hline Bacilus sp. & 12 & 80.0 \\
Proteus sp. & 3 & 20.0 \\
Salmonella sp. & 3 & 20.0 \\
Pseudomonas sp. & 3 & 26.6 \\
Klebsiella sp. & 3 & 20.0 \\
Escheria Coli sp. & 5 & 33.3 \\
Staphylococcus sp. & 5 & 33.3 \\
Mucor sp. & 1 & 6.7 \\
Aspergillus sp. & 2 & 13.3 \\
\hline
\end{tabular}




\subsection{Histopathological assessment of Synodontis Clarias intestine}

The photomicrographs of the histopathological assessment of the infected intestines of Synodontis clarias in the Lagoon showed severe stunting of the villous structure (thick arrow), presence of detritus (thin arrow) within the lumen (Figure $4 \mathrm{~A}, \mathrm{~B}$, and D), and mild fibrosis (thin arrow) of the villi structure. Thrombosis (black arrow) was also observed within the muscularis (Figure $4 \mathrm{E}$ and F). Normal villous architectural structures were well preserved among the uninfected fish (Figure $4 \mathrm{C}, \mathrm{G}$, and $\mathrm{H}$ ).
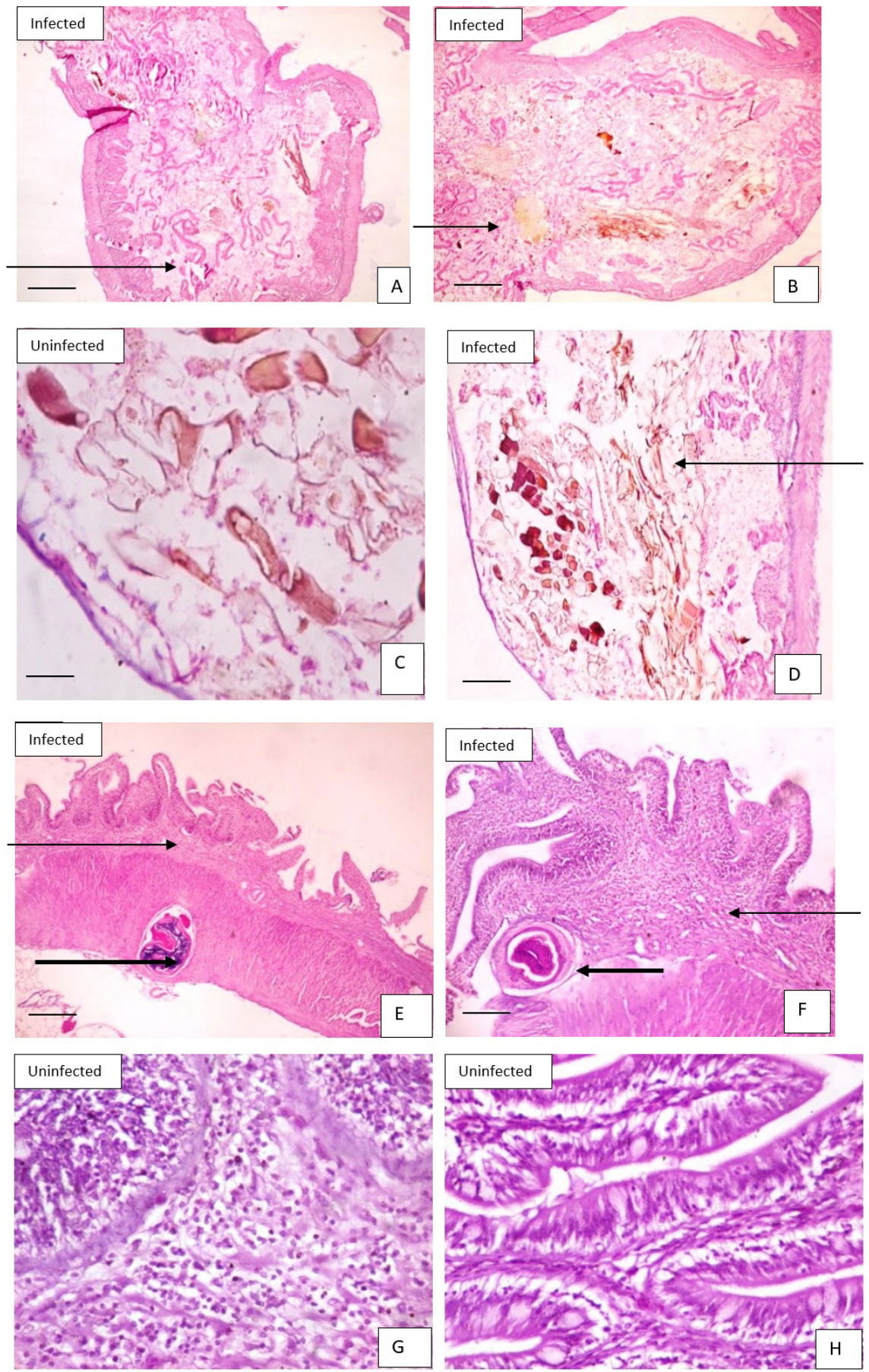

Figure 4. A, B and D are photomicrographs of intestinal tissue showing severe stunting of the villous structure (black arrow) and presence of detritus (slender arrow) within the lumen. E and F are intestinal tissue showing mild fibrosis (slender arrow) of the villi structure and thrombosis (black arrow) within the muscularis. While $\mathrm{C}, \mathrm{G}, \mathrm{H}$ showed normal villous architectural structures were well preserved. 


\section{Discussions}

The neurotoxic effects of synthetic pyrethroids such as deltamethrin are initiated by blocking sodium channels and inhibiting the gamma-aminobutyric acid (GABA) receptors in the nervous filament which results in excessive stimulation of the central nervous system which can ultimately lead to brain hypoxia. Further studies on toxicokinetics and toxicodynamics of pyrethroids in aquatic organisms is essential for guiding public health decisions (Boulton, 1999; Meyer, 1997; Gilliom et al., 2007; Aktar et al., 2009).

The surface water of the lagoon was acidic throughout the sampling period. The acidic condition of the lagoon may foster the bioavailability of the inherent toxicants. The heightened temperature in the month of November is attributable to increased sun intensity and no rainfall in the dry season which was accompanied by high total dissolved solids (Emmanuel and Chukwu, 2010). A similar trend was earlier recorded in the lagoon by Opadokun et al. (2015) with a mean temperature of $28.73{ }^{\circ} \mathrm{C} \pm 1.83{ }^{\circ} \mathrm{C}$.

Although the fish exhibited perfect condition factor, the microbial susceptibility of the infected fish however suggests that immunosuppression might have occurred in the fish following exposure to pyrethroids from improper waste disposal, along the coastal area of the lagoon. Akinsanya et al. (2015) earlier examined the effects of anthropogenic-induced environmental perturbations on parasitic organisms at both the population and the community levels. Types of stressors implicated include municipal sewage and industrial effluents, which may cause eutrophication and acidification; among other devastating ecological phenomena (Marcogliese, 2004).

Bacterial strains from the genera Bacillus, Pseudomonas, Raoultella, Achromobacter, Acidomonas, Brevibacterium, Pseudomonas, Streptomyces, Serratia, Sphingobium, Clostridium, Klebsiella, and Lysinibacillus have been characterized for pyrethroid degradation (Chandola et al., 2011; Gupta et al., 2012). In this study, there was a high prevalence of gut microbes (30 - 40\%), which include Salmonella sp, Escherichia coli, Pseudomonas sp, and Bacillus sp among individuals infected with gut Cestodes, Wenyonia acuminata compared to the uninfected individual which had higher gut Staphylococcus sp., Klebsiella sp., and Proteus sp. (10-40\%).

Pyrethroids are synthetic chemicals modeled after the pyrethrin components of pyrethrum, a naturally occurring chemical found in certain chrysanthemum flowers (National Pesticide Information Center, 2010). Modern synthetic pyrethroids have been designed to provide enhanced residual activity with greater photostability and high cost-effectiveness. The overall impact is greater in the aquatic environment, as pesticides and other xenobiotics are transported to greater distances in the hydrosphere affecting many more non-target organisms.

In this study, among the congeners of pyrethroids analyzed, Cyfluthrin $>$ Alpha-Cypermethrin had significant sorption on the sediment, however unlike a benthopelagic fish; S. clarias didn't accumulate any pyrethroid from the sediment. The fish, however, accumulated Alpha-Cypermethrin from the aqueous phase. The parasite on the other hand accumulated Bathroid significantly from the environment. The intervention of the parasite may be linked to the higher stress observed in the parasite than the host fish.

The sorption of Cyfluthrin and Alpha-Cypermethrin from the aqueous phase to the bottom sediment in the lagoon may result in future re-pollution of the overlying water column. If sorption progresses indefinitely, S. clarias may suffer an excessive accumulation of the toxicants in the intestine, being a benthopelagic feeder.

$W$. acuminata showed some tendencies of depurating Cyfluthrin and Baythroid (Beta-Cypermethrin) from the intestine of the fish. This may have partly contributed to lower bioaccumulation of the pyrethroid congeners in the intestine that the liver of the fish. Few congeners of pyrethroids detected in the water might be as a result of their high decomposition rate when exposed to sunlight. Also, the presence of 2 isomers of cypermethrin can be attributed to their wide use in households, agriculture, and industries for controlling several insects. The higher concentration of pyrethroid in the sediment than the surface water and the biota conforms to previous literature (Yim et al., 2005; Qadir and Malik, 2011; Wei et al., 2014; Ccanccapa et al., 2016; Akoto et al., 2016).

Oxidative stress is induced by many chemical pollutants at sub-lethal concentrations. Reactive oxygen species (ROS) are common by-products of normal aerobic cellular metabolism and play important physiological roles in intracellular cell signaling and the maintenance of homeostasis. However, living organisms are equipped with antioxidant defense systems, consisting of both enzymatic and non-enzymatic antioxidants, to regulate the levels of these free radicals. Oxidative stress occurs due to an imbalance between the production of ROS and the ability of the antioxidant systems to readily detoxify these reactive intermediates. The free radicals generated oxidative stress conditions can lead to DNA, lipid, and protein damage resulting in complicated health issues (Birben et al., 2012).

To protect against reactive oxygen species, cells possess specific antioxidant enzymes such as superoxide dismutase (SOD), catalase (CAT), and glutathione peroxidase (GPx), which decompose superoxide anion radical (SOD) and hydrogen peroxide. Glutathione S-transferases (GST) catalyze the conjugation of glutathione (GSH) to electrophilic xenobiotics and oxidized components. Moreover, complementary enzymes such as glutathione reductase and glucose-6-phosphate dehydrogenase (G6PDH) produce GSH and NADPH to maintain cellular antioxidant status (Almeida et al., 2005). The extent of lipid peroxidation is determined by the balance between the production of oxidants and their removal and scavenging by antioxidants (Wilhelm Filho, 1996). It is shown that lipid peroxidation (MDA) estimation could provide useful information about the exposure to aquatic pollutants. In this study, the levels of GSH and protein were higher 
in the liver of the studied fish compared to the amount in the intestinal parasite whereas the activities of CAT, SOD, GPx, and MDA were, in turn, higher in the parasite. The differences observed can be as a result of functional differences in the two studied organs. The liver is the main organ for detoxification in vertebrates and thus center for the breakdown of metabolic products (Lee et al., 2015) and is constantly attacked by both internal and external free radicals. The intestine, on the other hand, harbored the parasites is the organ for digestion of food and is attacked by endogenic radicals and diet-derived oxidants (Lushchak et al., 2015; Opadokun et al. 2105). However, the antioxidant defense is more effective in the liver than other organs. Oxidative stress effects of pyrethroids have been reported in Oreochromis niloticus and Cyprinus carpio exposed to $3 \mu \mathrm{g} \mathrm{L}^{-1}$ cypermethrin for 10 days, which caused SOD, CAT and MDA levels in the liver to increase significantly. GPx activity increased in the liver of O. niloticus while it decreased in C. carpio. The changes in GPx activity according to Uner et al. (2001) may be related to the excess. $\mathrm{O}^{2-}$ resulting in increased SOD activity in the exposed fish (Gupta et al., 2012; Akinsanya et al. 2015).

A study on a broad spectrum insecticide, composed of a mixture of organophosphates and pyrethroids (fenitrothion 25\%, lambda-cyhalothrin $2.5 \%$ and piperonyl butoxide $6 \%$ ), and the antioxidant status and oxidative stress biomarkers in rat brain by El-Demerdash (2011) resulted in a significant increase $(\mathrm{p}<0.05)$ in thiobarbituric acid reactive substances, which might be associated with decreased levels of GSH, SOD, CAT, GST and acetylcholinesterase activities beside protein content in the rat brain. In light of past observations, the parasites in the current study might have shared the toxicity burden of the fish (Marcogliese, 2005).

In the present study, histological examination showed that the intestine of the fish might have been impacted by $W$. acuminata, marked by moderate inflammation of the mucosa, alteration of the villi microstructure, moderate stunting of the villous structure and moderate fibrosis of villous structure. Teh et al. (2005) also observed histopathological lesions in the liver of Pogonichthys macrolepidotus after 96-h exposure to sublethal concentrations of organophosphate and pyrethroid insecticides.

\section{Conclusion}

The study demonstrated the efficiency of histopathological and microbial analysis in biomonitoring studies enteric parasites and early detection of pyrethroid toxicity respectively compared to bioaccumulation analysis. Although concentrations of pyrethroid were low in the fish, which was supported by good condition factor, the microbial analysis however proved to be more sensitive to sub-lethal toxicity.

The oxidative stress expressed by the parasite might have been due to interactions with toxicants in the host. This suggests that the parasites may possibly have a significant share of toxicant burden (Akinsanya et al., 2020) while inflicting injury on the host in return. This finding suggests that $W$. acuminata may not be a good candidate for depuration of pyrethroids in S. clarias. This however remains the hypothetical pending determination of the sequestration tendencies at higher concentrations. Hence further study on the depurative capacity of $W$. acuminata on pyrethroid burden in C. clarias is recommended.

The result obtained from this research can be used as baseline data for pollution assessment, and a guide for future biomonitoring in the lagoon.

\section{Acknowledgments}

The research was sponsored by the Central Research Committee, University of Lagos, Akoka, Nigeria.

\section{References}

AKINSANYA, B., ISIBOR, P.O., ADEMOLA, E., DADA, E., SALIU, J. and OLASEHINDE, G., 2020. Accumulation of PCBs and infections of parasitic helminthes in Synodontis filamentosus (Boulenger, 1901) and Tilapia zillii (Gervais, 1848) of Epe Lagoon, Lagos, Nigeria. Egyptian Journal of Aquatic Biology \& Fisheries, vol. 24 , no. 1 , pp. 49-63.

AKINSANYA, B., ISIBOR, P.O., KUTON, M.P., DADA, E.O. and SALIU, J.K., 2019. Comparative partition coefficient of OCPs between Synodontis clarias and parasite Weyonia acuminate. Journal of Basic \& Applied Zoology, vol. 80, no. 38, pp. 1-9. http://dx.doi.org/10.1186/s41936-019-0090-6.

AKINSANYA, B., KUTON, M.P., SALIU, J.K., OYEBOLA, L. and UKWA, U.D., 2015. Condition factor and gastrointestinal parasitic fauna of three fish species as stress indicators in lekki lagoon, Lagos, Nigeria. Egyptian Academic Journal of Biological Sciences, vol. 7, no. 1, pp. 1-13.

AKINSANYA, B., OTUBANJO, O.A. and IBIDAPO, C.A., 2007. Helminth Bioload of Chrysichthys nigrodigitatus (Lacepede 1802) from Lekki Lagoon Lagos, Nigeria. Turkish Journal of Fisheries and Aquatic Sciences, vol. 7, pp. 83-87.

AKOTO, O., AZUURE, A.A. and ADOTEY, K.D., 2016. Pesticide residues in water, sediment and fish from Tono Reservoir and their health risk implications. SpringerPlus, vol. 5, no. 1, pp. 1849. http://dx.doi.org/10.1186/s40064-016-3544-z. PMid:27818887.

AKTAR, M.W., SENGUPTA, D. and CHOWDHURY, A., 2009. Impact of pesticides use in agriculture: their benefits and hazards. Interdisciplinary Toxicology, vol. 2, no. 1, pp. 1-12. http://dx.doi. org/10.2478/v10102-009-0001-7. PMid:21217838.

ALANI, R., OLAYINKA, K. and ALO, B., 2013. The level of persistent, bioaccumulative and toxic (PBT) organic micropollutants contamination of Lagos soils. Journal of Environmental Chemistry and Ecotoxicology, vol. 5, pp. 26-38.

ALMEIDA, E.A., BAINY, A.C.D., DAFRE, A.L., GOMES, O.F., MEDEIROS, M.H.G. and DI MASCIO, P., 2005. Oxidative stress in digestive gland and gill of the brown mussel (Perna perna) exposed to air and re-submersed. Journal of Experimental Marine Biology and Ecology, vol. 318, no. 1, pp. 21-30. http://dx.doi. org/10.1016/j.jembe.2004.12.007.

ANGAHAR, L.T., 2017. Investigations of acute toxicity and neurotoxin effects of aqueous extracted pyrethroid (deltamethrin) from insecticide treated mosquito net on clarias gariepinus and 
heterobranchus bidorsalis. MOJ Biological and Medicine, vol. 1, no. 4, pp. 36487140. http://dx.doi.org/10.15406/MOJBM.2017.01.00020.

ARTHUR, J.R., 2000. The glutathione peroxidases. Cellular and Molecular Life Sciences, vol. 57, no. 14, pp. 1825. PMid:11215509.

AYEJUYO, O.O., WILLIAMS, A.B. and IGBASAN, S.O., 2008. Assessment of Organochlorine Pesticide Residues in Irrigation Groundwater of Lagos. Journal of Chemical Society of Nigeria, vol. 33, no. 1, pp. 65-69.

AYOOLA, S.O. and AJANI, E.K., 2008. Histopathological Effects of Cypermethrin on Juvenile African Catfish (Clarias gariepinus). World Journal Biological Resources, vol. 1, no. 2, pp. 1-14.

BIRBEN, E., SAHINER, U.M., SACKESEN, C., ERZURUM, S. and KALAYCI, O., 2012. Oxidative stress and antioxidant defense. The World Allergy Organization Journal, vol. 5, no. 1, pp. 9-19. http://dx.doi.org/10.1097/WOX.0b013e3182439613. PMid:23268465.

BOULTON, A.J., 1999. An overview of river health assessment; philosophies, practice, problems and prognosis. Biology (Basel), vol. 41, pp. 461-479.

CCANCCAPA, A., MASIA, A., NAVARRO-ORTEGA, A., PICO, Y. and BARCELO, D., 2016. Pesticides in the Ebro River basin: occurrence and risk assessment. Environmental Pollution, vol. 211, pp. 414-424. http://dx.doi.org/10.1016/j.envpol.2015.12.059. PMid:26802514.

CHANDOLA, M., RATHORE, M. and KUMAR, B., 2011. Indigenous pest management practices prevalent along the hill farmers of Uttarakhand. Indian Journal of Traditional Knowledge, vol. 10 , no. 2 , pp. 311-315.

COORDENAÇÃO DE PROJETOS DE COOPERAÇÃO NACIONAL-CPCN, 2001. Compendium of Pesticide Common name Pyrethroid insecticide. Brasília: CPCN, pp. 42-45.

CUI, X., HUNTER, W., YANG, Y., CHEN, Y. and GAN, J., 2010. Bioavailability of sorbed phenanthrene and permethrin in sediments to Chironomus tentans. Aquatic Toxicology (Amsterdam, Netherlands), vol. 98, no. 1, pp. 83-90. http://dx.doi.org/10.1016/j. aquatox.2010.01.016. PMid:20170969.

EL-DEMERDASH, F.M., 2011. Lipid peroxidation, oxidative stress and acetylcholinesterase in rat brain exposed to organophosphate and pyrethroid insecticide. Food and Chemical Toxicology, vol. 49, no. 6, pp. 1346-1352. http://dx.doi.org/10.1016/j.fct.2011.03.018. PMid:21419823.

ELLMAN, G.L., 1959. Tissue sulfhydryl groups. Archives of Biochemistry and Biophysics, vol. 82, pp. 70-77. http://dx.doi. org/10.1016/0003-9861(59)90090-6.

EMMANUEL, B. E. and CHUKWU, L. O., 2010. Spatial distribution of saline water and possible sources of intrusion into a tropical freshwater lagoon and the transitional effects on the Lacustrine Ichthyofaunal diversity. Africa Journal of Environment Science and Technology, vol. 4, pp. 480-491.

FOOD AND AGRICULTURE ORGANIZATION OF THE UNITED NATIONS - FAO, 1996. Parasites, infections and diseases of fishes in Africa - an update. Rome: FAO. CIFA Technical Paper, no. 31, pp. 220.

GILLIOM, R.J., BARBASH, J.E., CRAWFORD, G.G., HAMILTON, P.A., MARTIN, J.D., NAKAGAKI, N., NOWELL, L.H., SCOTT, J.C., STACKELBERG, P.E., THELIN, G.P. and WOLOCK, D.M., 2007. The Quality of our nation's waters: Pesticides in the nation's streams and ground water. Reston: US Geological Survey.
GUPTA, S.K., PAL, A.K., SAHU, N.P., SAHARAN, N., MANDAL, S.C., CHANDRAPRAKASH, A.M.S. and PRUSTY, A.K., 2012. Dietary microbial levan ameliorates stress and augments immunity in Cyprinus carpio fry (Linnaeus, 1758) exposed to sublethal toxicity of fipronil. Aquaculture Resources, vol. 45, pp. 11-20.

IDODO-UMEH, G., 2003. Freshwater Fishes of Nigeria (Taxonomy, Ecological notes, Diet and Utilization). Nigéria: Idodo Umeh Publishers Limited, pp 408.

KORKMAZ, N., CENGIZ, E.I., UNLU, E., UYSAL, E. and YANAR, M., 2009. Cypermethrin-induced histopathologica and biochemical changes in Nile tilapia (Oreochromis niloticus), and the protective and recuperative effect of ascorbic acid. Environmental Toxicology and Pharmacology, vol. 28, no. 2, pp. 198-205. http:// dx.doi.org/10.1016/j.etap.2009.04.004. PMid:21784003.

KRONVANG, B., IVERSEN, H.L., VEJRUP, K. and MOGENSEN, B.B., 2003. Pesticides in streams and subsurface drainage water within two arable catchments in Denmark: pesticide application, concentration, transport and fate. Pesticide Resources, vol. 69.

KUSEMIJU, K., 1981. The hydrobiology and fishes of the Lekki lagoon. Nigeria Journal of Natural Sciences, vol. 3, pp. 135-146.

LASKOWSKI, D.A., 2002. Physical and chemical properties of pyrethroids. Reviews of Environmental Contamination and Toxicology, vol. 174, pp. 49-170. http://dx.doi.org/10.1007/9781-4757-4260-2_3. PMid:12132343.

LE-CREN, E.D., 1951. The weight-length relationship and seasonal cycle in gonad weight and the condition in Perch (Perca fluviatilis). Journal of Animal Ecology, vol. 20, pp. 201-219.

LEE, J.W., CHOI, Y.C., KIM, R. and LEE, S.K., 2015. Multiwall carbon nanotube-induced apoptosis and antioxidant gene expression in the gills, liver, and intestine of Oryzias latipes. BioMed Research International, vol. 2015, pp. 1-10. PMid:26146619.

LUSHCHAK, V.I., BAGNYUKOVA, T.V., LUSHCHAK, O.V., STOREY, J.M. and STOREY, K.B., 2015. Hypoxia and recovery perturb free radical processes and antioxidant potential in common carp (Cyprinus carpio) tissues. Int J. Biochemistry and Cell Biology, vol. 37, no. 6, pp. 1319-1330. http://dx.doi. org/10.1016/j.biocel.2005.01.006.

MARCOGLIESE, D.J., 2004. Parasites: small players with crucial roles in the ecological theatre. EcoHealth, vol. 1, no. 2, pp. 151164. http://dx.doi.org/10.1007/s10393-004-0028-3.

MARCOGLIESE, D.J., 2005. Parasites of the superorganism: are they indicators of ecosystem health? International Journal for Parasitology, vol. 35, no. 7, pp. 705-716.

MARKLUND, S. and MARKLUND, G., 1974. Involvement of the Superoxide Anion Radical in the Autoxidation of Pyrogallol and a Convenient Assay for Superoxide Dismutase. European Journal of Biochemistry, vol. 47, no. 3, pp. 469-474. http:// dx.doi.org/10.1111/j.1432-1033.1974.tb03714.x. PMid:4215654.

MEYER, J.L., 1997. Stream health incorporating the human dimension to advance stream ecology. Journal of America Benthological Society, vol. 16, no. 2, pp. 439-447. http://dx.doi. org/10.2307/1468029.

MOORE, A. and WARING, C.P., 2001. The effects of a synthetic pyrethroid pesticide on some aspects of reproduction in Atlantic Salmon (Salmo salar L.). Aquatic Toxicology (Amsterdam, Netherlands), vol. 52, no. 1, pp. 1-12. http://dx.doi.org/10.1016/ S0166-445X(00)00133-8. PMid:11163426. 
NATIONAL PESTICIDE INFORMATION CENTER, 2010. Technical Fact Sheet. National Pesticide Information Center. Nature, vol. 418, pp. 671-677.

OJO, J., 2016. Pesticides use and health in Nigeria. Ife Journal of Science, vol. 18, no. 4, pp. 981-991.

OLAOSEBIKAN, B.D. and RAJI, A., 1998. Field guide to Nigerian freshwater fishes. Nigéria: Federal College of Freshwater Fisheries Technology, pp. 202.

OPADOKUN, I.O., FALAYE, A.E. and AJANI, E.K., 2015. Seasonal variation in physicochemical parameters of Lekki Lagoon and the conservation of its ecosystem. Journal of Geoscience and Environment Protection, vol. 3, no. 9, pp. 11-17. http://dx.doi. org/10.4236/gep.2015.39002

QADIR, A. and MALIK, R.N., 2011. Heavy metals in eight edible fish species from two polluted tributaries (Aik and Palkhu) of the River Chenab. Biological Trace Element Research, vol. 143, no. 3, pp. 1524-1540. http://dx.doi.org/10.1007/s12011-011-9011-3. PMid:21424780.

QUINLAN, T., SPIVAK, S., and MOSSMAN, B.T., 1994. Regulation of antioxidant enzymes in lung after oxidant injury. Environmental Health Perspective, vol. 102, suppl 2, pp. 79-87. http://dx.doi.org/10.1289/ehp.9410279.

SALIU, J.K., AKINSANYA, B., UKWA, U.D., ODOZIE, J., and GANIU, Y., 2014. Host condition, parasite interaction and metal accumulation in Tilapia guineensis from Iddo area of Lagos Lagoon, Nigeria. Iran Journal Ichthyology, vol. 1, pp. 286-296.

SCHLEIER 3RD, J.J. and PETERSON, R.K.D., 2013. A refined aquatic ecological risk assessment for a pyrethroid insecticide used for adult mosquito management. Environmental Toxicology and Chemistry, vol. 32, no. 4, pp. 948-953. http://dx.doi.org/10.1002/ etc.2126. PMid:23341175.

SINGH, M., MULLER, G. and SINGH, I.B., 2002. Heavy metals in freshly deposited stream sediments of rivers associated with urbanization of the Ganga plain, India. Water, Air, and Soil Pollution, vol. 141, no. 1/4, pp. 35-54. http://dx.doi. org/10.1023/A:1021339917643.

SOFOLUWE, N.A., TIJANI, A.A. and OGUNDARI, K., 2013. Indigenous technology adoption and poverty reduction in rural Nigeria. Indigenous Policy Journal, vol. 23, pp. 1-15.

SPURLOCK, F. and LEE, M., 2008. Synthetic Pyretyhroid use patterns, properties and environmental effects. In: Proceedings of the ACS Symposium Series, 2008, Washington. Washington:
American Chemical Society, vol. 991, pp. 3-25 http://dx.doi. org/10.1021/bk-2008-0991.ch001.

SURES, B., 2008. Environmental parasitology. Interactions between parasites and pollutants in the aquatic environment. Parasite (Paris, France), vol. 15, no. 3, pp. 434-438. http://dx.doi. org/10.1051/parasite/2008153434. PMid:18814718.

TEH, S.J., DENG, D.F., WERNER, I., TEH, F.C. and HUNG, S.S.O., 2005. Sublethal toxicity of orchard stormwater runoff in Sacramento splittail (Pogonichthys macrolepidotus) larvae. Marine Environmental Research, vol. 59, no. 3, pp. 203-216. http:// dx.doi.org/10.1016/j.marenvres.2003.12.005. PMid:15465130.

ÜNER, N., ORUÇ, E.Ö., CANLI, M. and SEVGLER, Y., 2001. Effects of cypermethrin on antioxidant enzyme activities and lipid peroxidation in liver and kidney of the freshwater fish, oreochromis niloticus and Cyprinus carpio (L.). Bulletin of Environmental Contamination and Toxicology, vol. 67, no. 5, pp. 657-664. http://dx.doi.org/10.1007/s00128-001-0174-z. PMid:11911634.

VELISEK, J., WLASOW, T., GOMULKA, P., SVOBODOVA, Z., DOBSIKOVA, R., NOVOTNY L., and DUDZIK, M., 2006. Effects of cypermethrin on rainbow trout (Oncorhynchus mykiss). Veterinární Medicína, vol. 51, no. 10, pp. 469-476. http://dx.doi. org/10.17221/5580-VETMED.

WEI, Y., ZHANG, J., ZHANG, D., TU, T. and LUO, L., 2014. Metal concentrations in various fish organs of different fish species from Poyang Lake, China. Ecotoxicology and Environmental Safety, vol. 104, pp. 182-188. http://dx.doi.org/10.1016/j. ecoenv.2014.03.001. PMid:24681447.

WERNER, I. and MORAN, K., 2008. Effects of pyrethroid insecticides on aquatic organisms. In: Proceedings of the ACS Symposium Series, 2008, Washington. Washington: American Chemical Society, vol. 991, pp. 310-334 http://dx.doi.org/10.1021/ bk-2008-0991.ch014.

WILHELM FILHO, D., 1996. Fish antioxidant defences: a comparative approach. Brazilian Journal of Medical and Biological Research, vol. 29, pp. 1735-1742.

YANG, W., SPURLOCK, F., LIU, W. and GAN, J., 2006. Inhibition of aquatic toxicity of pyrethroid insecticides by suspended sediment. Environmental Toxicology and Chemistry, vol. 25, no. 7, pp. 1913-1919. http://dx.doi.org/10.1897/05-616R.1. PMid:16833154.

YIM, U.H., HONG, S.H., SHIM, W.J. and OH, J.R., 2005. Levels of persistent organochlorine contaminants in fish from korea and their potential health risk. Archives of Environmental Contamination and Toxicology, vol. 48, no. 3, pp. 358-366. http://dx.doi.org/10.1007/s00244-004-0085-1. PMid:15719194. 